\title{
Evaluation of Genotoxic Risks Due to Temporal Changes in Soil Urea: Using Allium cepa L. Root Tip Bioassay
}

\author{
Kavita Arora, Namrata Singh, Shipra Srivastava, and Alka Srivastava* \\ In Vitro Culture and Plant Genetics Unit, Department of Botany, \\ University of Lucknow, Lucknow-226007, (U.P.) India \\ Received July 18, 2013; accepted December 11, 2013
}

\begin{abstract}
Summary Breakdown of soil urea yields ammonium ions or ammonia, which further converts to nitrite and nitrate due to nitrification. These breakdown products have severe toxic effects on the crop standing in the soil when present in high concentrations. Temporal changes in ammoniumnitrate ratio following urea application in soil and its consequent genotoxic effects were assessed. In an in vitro experiment, a treatment of different concentrations of urea was given to Allium cepa bulbs for different durations to optimize the concentration on the basis of root tip bioassay for minimum aberrations. Further, the effect of temporal changes in urea in the soil system was studied by a pot experiment in which urea was added to the soil at a rate of $200 \mathrm{mg} \mathrm{N} \mathrm{kg}^{-1}$ soil (optimized from in vitro experiment). A regular intervals for four weeks, the roots from the onion bulbs were fixed and cytological analysis was done. Estimation of ammonium and nitrate was done on corresponding days. The cytological analysis of root tips harvested in both in vitro and pot experiments revealed dividing cells and different types of division anomalies. Variation was observed in the percentage of mitotic index and percentage of anomalous cells during the span of the experiments. In the case of the pot experiment, the abnormalities observed were of two distinct types (i) mitotic abnormalities, i.e., abnormalities in dividing cells, and (ii) interphase nuclear abnormalities. The varying ratio of ammonium and nitrate with respect to time has been considered as a possible reason for such variations in nuclear behaviour.
\end{abstract}

Key words Ammonium-nitrate ratio, Genotoxicity, Interphase nuclear abnormality, Mitotic abnormality, Temporal change.

Fertilizers are often chemically derived and are used to improve the fertility of soil for high crop yield. The use of fertilizers to augment crop production is increasing day by day, especially in developing countries due to population growth and a dearth of good agricultural land. Nitrogen (N) being the most essential nutrient for plant growth holds the biggest share among other nutrients/ fertilizers. Urea, which contains $46 \% \mathrm{~N}$, is the most popular $\mathrm{N}$ fertilizer. Urea hydrolysis yields ammonium ion/ammonia and carbon dioxide. Ammonium further converts into nitrate via nitrification process. To increase crop productivity, not only an optimal N-fertilizer application rate, but also an optimal ratio between ammonium, nitrate and urea in the soil are important (Bar-Yosef et al. 2009). An important role of the ammonium to nitrate ratio is to balance the rhizospheric $\mathrm{pH}$. The effect of $\mathrm{NH}_{4}: \mathrm{NO}_{3}$ on crop plants was studied by several workers (Cabrera 2001, Taghavi et al. 2004, Bar-Yosef et al. 2009). Accumulation of either $\mathrm{NH}_{4}$ or $\mathrm{NO}_{3}$ in the soil is toxic to plants as has been reported by earlier workers (Britto and Kronzucker 2002, Okushima et al. 2011, Qin et al. 2011, Qi et al. 2012). Elevated levels of these nutrients are not only toxic; they can also cause blooms in primary productivity. Reports also suggest that $\mathrm{NH}_{4}$ is universally toxic, but its toxicity

\footnotetext{
* Corresponding author, e-mail: alkasrivastava@hotmail.com

DOI: $10.1508 /$ cytologia. 79.85
} 
levels at which symptoms of toxicity become evident differ widely among plant species (Britto and Kronzucker 2002). Symptoms of $\mathrm{NH}_{4}^{+}$toxicity vary from chlorosis of leaves to overall suppression of growth, and in extreme cases can result in death. Higher concentrations of ammonium inhibit seed germination and seedling germination. Another characteristic manifestation is the inhibition of primary root growth (Britto and Kronzucker 2002). Similarly, nitrate at higher concentrations represses lateral root development prior to activation of the lateral root meristem (Zhang and Forde 2000). Plant growth characters are controlled by cell division, which are affected by treatment with agrochemicals. However, the subtle danger of widespread use of such chemicals lies in the possibility of their causing mutation of somatic cells, resulting in the accumulation of heritable abnormal genes in the population or the formation of malignant cells in the individuals. The toxicants that act on DNA cause damage to the genome, including alterations in the nucleic acids, and result in the modification or activation of a cell's genome; these toxicants are classified as "genotoxic". Genotoxic and cytotoxic effects of fertilizers on plants have been shown by Koca (2008) and Khaldi et al. (2012), respectively. In the present study, Allium cepa has been used to assay the genotoxic effects of urea because it has been considered as an excellent material for the assay of chromosomal aberration following chemical treatment. Its root meristem represents a normal proliferating plant cell population that is sensitive to changes in environmental conditions. Genotoxicity of soil due to radioactive material was successfully measured using an $A$. серa chromosome aberration test (Kovalchuk et al. 1998). The $A$. cepa test provides a rapid screening procedure for chemicals, pollutants, contaminants, etc., which may represent environmental hazards.

\section{Materials and methods}

\section{In vitro experiment}

The cytotoxic effect of urea was monitored by using the $A$. cepa $(2 n=16)$ as a test system. Healthy bulbs of the onion were taken, and the base of the bulbs was scrapped, leaving the root primordia intact, and placed on test tubes containing different concentrations, viz., $0.01 \%, 0.05 \%$, $0.1 \%, 0.25 \%$ and $0.5 \%(\mathrm{w} / \mathrm{v})$, of urea in water for germination, along with the control on distilled water, in such a way that the base was in contact with the water/solution. The exposure schedule depended on the time taken by the bulbs for germination of the root up to a length of 2 to $3 \mathrm{~cm}$. The minimum germination time was 3 to $5 \mathrm{~d}$, and then the root tips were fixed along with the roots of the control. Experiments were carried out at room temperature and protected from direct sunlight. After $72 \mathrm{~h}$ of treatment, the length of the emerged root, growth percentage (percent control value), and root growth inhibition percentage were estimated. The root tips were then fixed in $1: 3$ acetic acid: ethanol solution for cytological studies.

Growth \% (Percent control value $)=\frac{\text { Average root length in treated plants }}{\text { Average root length in control plants }} \times 100$

Root growth inhibition $=$ Growth \% in control plants-Growth \% in treated plants

\section{Pot experiment}

Soil samples were collected from the garden of the Department of Botany at the University of Lucknow at a depth of $30 \mathrm{~cm}$ from an area that was not fertilized. One kilogram of sieved soil (passed through a 2-mm sieve) was air-dried and placed in pots. The physico-chemical properties of the soil used are given in Table 1 . The soil for the control did not receive any additives, while urea at the rate of $200 \mathrm{mg}-\mathrm{N} \mathrm{kg}^{-1}$ soil (standardized from in vitro experiments equivalent to $0.05 \%$ urea) was added to the soil for others. A. cepa was used for testing the effect of urea. For the 
Table 1. Physico-chemical properties of soil used.

\begin{tabular}{lc}
\hline \multicolumn{1}{c}{ Property } & Soil: Clay loam \\
\hline $\mathrm{pH}$ & 7.5 \\
Organic carbon (\%) & 0.34 \\
$\mathrm{NH}_{4}^{+}-\mathrm{N}\left(\mathrm{mg} \mathrm{kg}^{-1}\right.$ soil) & 43.4 \\
$\mathrm{NO}_{3}^{-}-\mathrm{N}\left(\mathrm{mg} \mathrm{kg}^{-1}\right.$ soil) & 3.8 \\
Maximum water-holding capacity (\%) & 32 \\
\hline
\end{tabular}

germination of $A$. cepa, locally obtained common medium-sized healthy onion bulbs were taken, and their outer scales were peeled out and the brownish bottom plates were removed carefully, leaving the ring of root primordia intact. Three bulbs were sown in each pot. The roots were harvested on every third day until $28 \mathrm{~d}$ after fertilizer treatment with regular intervals of $1,3,7,14$, 21 and $28 \mathrm{~d}$ after treatment (DAT). After harvesting the root, the fresh bulbs were planted in the control or urea-treated soil. The root tips were then fixed for cytological studies. The concentrations of ammonium-N $\left(\mathrm{NH}_{4}^{+}-\mathrm{N}\right)$ and nitrate- $\mathrm{N}\left(\mathrm{NO}_{3}^{-}-\mathrm{N}\right)$ present in the soil were quantified on day $1,3,7$, 14, 21 and 28 after the application of treatments by following the standard methods described by Jackson (1967) to record the temporal changes in urea breakdown products in the soil.

\section{Cytological preparations}

For cytological observations, the roots were fixed in Carnoy's fluid (1 part glacial acetic acid +3 part ethanol) for $24 \mathrm{~h}$ and then preserved in $70 \%$ ethanol. Fixation, hydrolysis and staining were done by following the method of Sharma and Sharma (1980). The mitotic study was carried out on temporary slides by observing the dividing cells and different types of division anomalies under a microscope with low and high power. The categories of aberrations scored included anaphase bridges, laggards, chromosomal fragmentation, aberrant metaphases and anaphases in dividing cells, micronuclei in interphase cells and presence of binucleate cells. The percentage of cells with chromosomal abnormalities or the relative abnormality rate (RAR), relative division rate (RDR), percent mitotic inhibition and mitotic index (\% MI) were calculated as follows.

$$
\begin{aligned}
& \text { MI }(\%)=\frac{\text { Total number of dividing cells }}{\text { Total number of cells observed }} \times 100 \\
& \text { RAR }(\%)=\frac{\text { Total number of abnormal cells }}{\text { Total number of cells observed }} \times 100 \\
& \text { RDR }(\%)=\frac{\% \text { dividing cells in treated material }-\% \text { dividing cells in control }}{\text { Total number of cells observed }} \times 100
\end{aligned}
$$

Mitotic Inhibition $(\%)=\frac{\text { Mitotic index of control }- \text { Mitotic index of treated variant }}{\text { Mitotic index of control }} \times 100$

\section{Statistical analysis}

The data were analyzed for significance using analysis of variance (ANOVA) and the differences contrasted using a Duncan's multiple range test (DMRT). All statistical analyses were performed using the SPSS statistical software package. 


\section{Results and discussion}

In vitro experiment

The forms of $\mathrm{N}$ supplied to plants affect the uptake of other cations and anions, cellular $\mathrm{pH}$ regulation, and the soil in the rhizosphere (Marschner 1995). Although plant species grow best if they have access to both nitrate and ammonium nitrogen, the preferred source of nitrogen (ammonium or nitrate) varies with species, cultivar and environmental factors (Errebhi and Wilcox 1990). In general, it has been found that plants that prefer acidic soil conditions seem to prefer ammonium, while those adapted to higher $\mathrm{pH}$ soils prefer nitrate. In the present investigation, the aim of the in vitro experiments was to find out the mitotoxic levels of urea. During our investigation of the phenotypic effects of urea on a sensitive plant species Allium, the maximum root growth was recorded in the control (distilled water), while a decreasing root growth was observed in the treated bulbs with increasing concentration of urea. The average root length decreased from $27.36 \pm 2.79 \mathrm{~mm}$ (control) to $10.08 \pm 0.61 \mathrm{~mm}(0.5 \%)$ after $3 \mathrm{~d}$ of treatment (Fig. 1). Higher levels of urea, i.e., 0.25 and $0.5 \%$, resulted in about 56 and $63 \%$ root growth inhibition, respectively (Fig. 1). Urea is reported to reduce seed germination and seedling growth due to ammonia toxicity. Urea adversely affected the seed germination percentage, shoot fresh weight, and root growth weight in a rice variety due to ammonia toxicity (Qi et al. 2012). At the chromosomal level, it was found that no chromosomal aberrations were present in the control population, but numerous abnormal cells were found in treated root tips. The cytological observations from the treated root tips revealed that the present treatment with urea not only brought down the number of dividing cells but also produced a good number of abnormalities in mitotic cells and in non-dividing cells. Mitotoxicity was estimated in terms of the change in mitotic index when compared to the control. The frequency of abnormal cells increased with increasing concentrations of urea, whereas the mitotic index was found to be inversely proportional to the concentration of urea. The mitotic index was maximum in the control at $23.68 \%$, and reduced to $5.97 \%$ in the $0.5 \%$ concentration of urea (Table 2 ). In consonance with our results, excess doses and longer periods caused a significant decrease in mitotic indices (Koca 2008). When compared to the control, mitotic inhibition progressively increased with increasing concentrations of urea. It was also observed that RDR gradually decreased and RAR increased in response to increasing concentrations of urea (Table 2). A drop in relative division rate with increasing concentrations of urea with a simultaneous increase in relative abnormality rate was observed (Table 2). There was an increase in total anomalies in dividing cells with an increase in concentration of urea. Chromatin

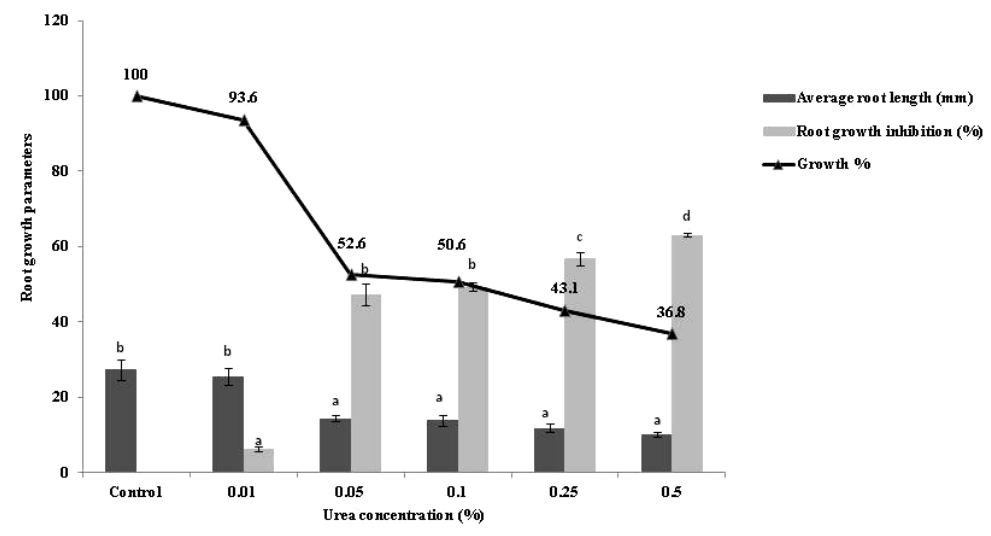

Fig. 1. Effect of different concentrations of urea on root growth parameters. Data are means \pm SE of three replicates. Bars with different letters are significantly different at $p \leq 0.05$ as determined by Duncan's multiple range test. 
Table 2. Effect of different concentrations of urea on cytological parameters in Allium cepa root tips. Values represent mean $\pm \mathrm{SE}$ in case of mitotic index and mean values followed by different superscript letters within column is significantly different at $p \leq 0.05$ as determined by Duncan's multiple range test.

\begin{tabular}{lcccccc}
\hline \hline $\begin{array}{c}\text { Treatment } \\
\text { urea (\%) }\end{array}$ & $\begin{array}{c}\text { Mitotic } \\
\text { index }(\%)\end{array}$ & $\begin{array}{c}\text { Mitotic } \\
\text { inhibition (\%) }\end{array}$ & $\begin{array}{c}\text { Metaphase } \\
\text { index }\end{array}$ & $\begin{array}{c}\text { Anaphase } \\
\text { index }\end{array}$ & $\begin{array}{c}\text { Relative } \\
\text { division rate }\end{array}$ & $\begin{array}{c}\text { Relative } \\
\text { abnormality rate }\end{array}$ \\
\hline Control & $23.68 \pm 0.58^{\mathrm{c}}$ & - & 3.584 & 7.294 & - & - \\
0.01 & $18.04 \pm 2.31^{\mathrm{b}}$ & 23.82 & 2.869 & 5.939 & -7.38 & 1.91 \\
0.05 & $16.2 \pm 1.15^{\mathrm{b}}$ & 31.59 & 2.072 & 4.851 & -9.80 & 2.17 \\
0.1 & $15.6 \pm 1.73^{\mathrm{b}}$ & 34.12 & 1.816 & 4.692 & -10.59 & 2.37 \\
0.25 & $13.9 \pm 2.31^{\mathrm{b}}$ & 41.30 & 1.012 & 4.282 & -12.80 & 2.57 \\
0.5 & $5.97 \pm 1.73^{\mathrm{a}}$ & 74.79 & 0.556 & 0.926 & -23.20 & 2.88 \\
\hline
\end{tabular}

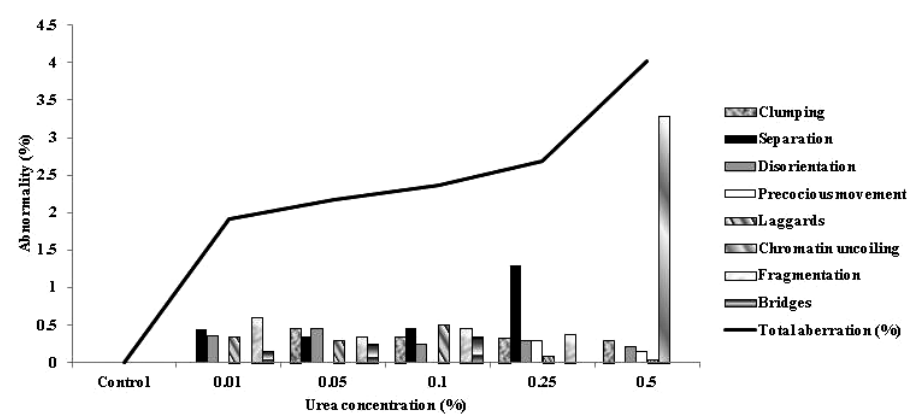

Fig. 2. Relative frequency of cytological aberrations induced by urea in Allium cepa under in vitro conditions.

uncoiling was only observed at a higher dose, i.e., $0.5 \%$. Disorientation of chromosomes and laggards prevailed at almost all the concentrations. The relative frequency of different cytological aberrations is shown in Fig. 2. Root growth inhibition and adverse effects on chromosomes provide an indication of likely toxicity. Morphological changes could be correlated to cytological changes.

\section{Pot experiment}

In the pot experiment, the effects of urea transformation products were studied at regular intervals of time. Urea ( $\mathrm{N}$-source) added in soil undergoes $\mathrm{N}$-transformations due to the presence of enzymes, microbes and soil microflora, resulting in the formation of ammonium/ammonia and finally nitrate through hydrolysis and nitrification, respectively. The soil $\mathrm{pH}$ increases temporarily in areas were urea has been applied due to hydrolysis of the urea by urease enzymes (Clay et al. 1990), and thus, accumulation of $\mathrm{NH}_{3}$ produced induces $\mathrm{NH}_{3}$ toxicity. Ammonium and nitrate are known to be paradoxical ions; plants take up nitrogen in these two inorganic forms, but both can result in toxicity symptoms when used as an exclusive nitrogen source. There was marked temporal variation observed in the concentrations of these transformation products of urea (ratio between $\mathrm{NH}_{4}$ and $\mathrm{NO}_{3}$ ) in the soil. These temporal fluctuations in $\mathrm{NH}_{4}: \mathrm{NO}_{3}$ coincided with cytological changes as revealed by our Allium root tip mitotic study. Similarly, the effect of $\mathrm{NH}_{4}: \mathrm{NO}_{3}$ : urea ratio on temporal $\mathrm{EC}$ and $\mathrm{pH}$ has been reported by Bar-Yosef et al. (2009) in roses in a closed system. The cytological analysis of root meristems treated with urea revealed a low mitotic index than the control from 1 DAT until 28 DAT (Fig. 3). Although abnormalities in dividing cells were observed at all intervals of time in the control as well as in the treated roots, it was higher in the treated roots. Errors during normal replication of genetic material and division appear as anomalies in mitotic preparations of root tips of the control (Fig. 5). Cell division in the treated roots increased 


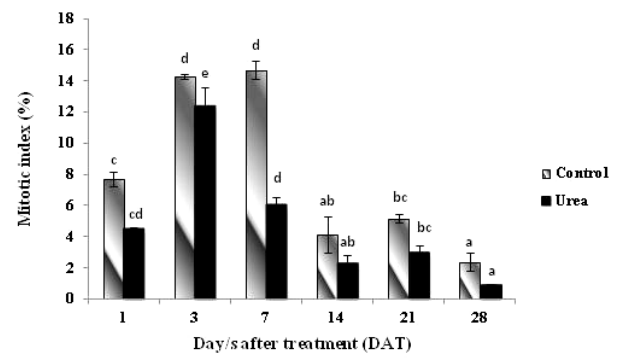

Fig. 3. Mitotic indices in the control and urea-treated plants at regular intervals of time. Data are means \pm SE of three replicates. Bars with different letters are significantly different at $p \leq 0.05$ as determined by Duncan's multiple range test.

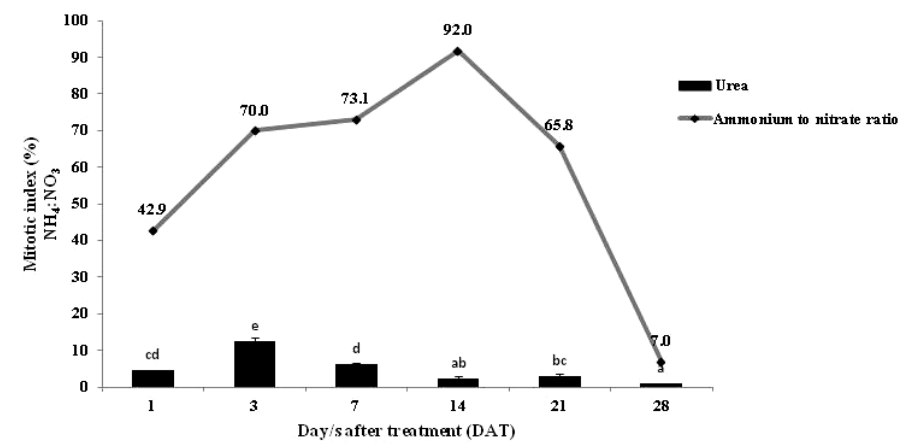

Fig. 4. Mitotic indices in urea-treated plants with $\mathrm{NH}_{4}: \mathrm{NO}_{3}$ at regular intervals of time. Data are means $\pm \mathrm{SE}$ of three replicates. Bars with different letters are significantly different at $p \leq 0.05$ as determined by Duncan's multiple range test.

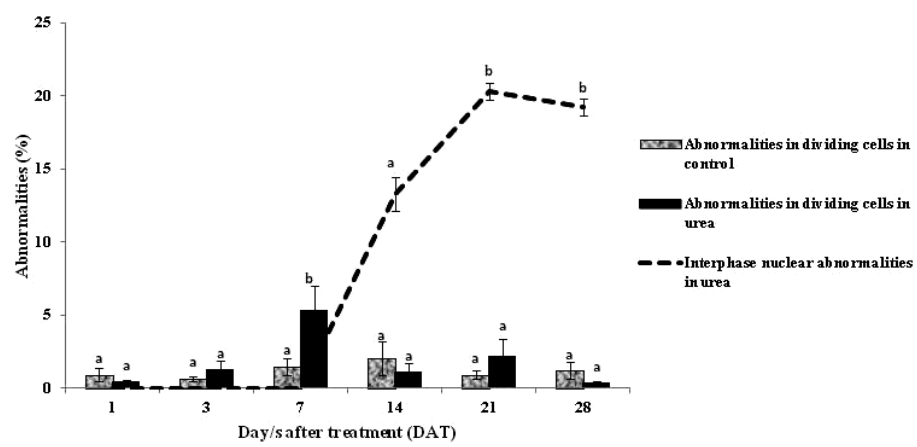

Fig. 5. Genotoxic effects of urea on root tip cells in the soil at regular intervals of time. Data are means $\pm \mathrm{SE}$ of three replicates. Bars with different letters are significantly different at $p \leq 0.05$ as determined by Duncan's multiple range test.

until 3 DAT and then declined as the days passed as evident by a sharp decrease in MI after 14 DAT until 28 DAT. During the first week, MI reaches a maximum on 3 DAT when $\mathrm{NH}_{4}: \mathrm{NO}_{3}$ is ca. $70-73 \%$, but as $\mathrm{NH}_{4}: \mathrm{NO}_{3}$ increased to $c a$. $90 \%$, there was a decline in MI. Additionally, on 7 DAT, abnormalities in dividing cells was at a maximum in cells of the treated root meristems, which may be asserted to higher levels of ammonia/ammonium during this period (Figs. 4-6). Figure 7 shows the type of abnormalities in dividing cells, such as laggards, clumping, bridge formation, etc. Our results are commensurate with the existing reports on ammonium/ammonia 


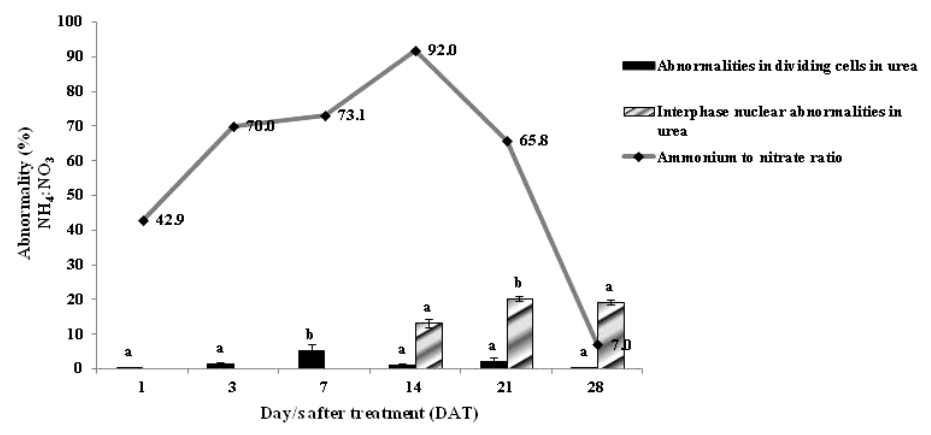

Fig. 6. Abnormalities (\%) in urea-treated plants with $\mathrm{NH}_{4}: \mathrm{NO}_{3}$ at regular intervals of time. Data are means $\pm \mathrm{SE}$ of three replicates. Bars with different letters are significantly different at $p \leq 0.05$ as determined by Duncan's multiple range test.

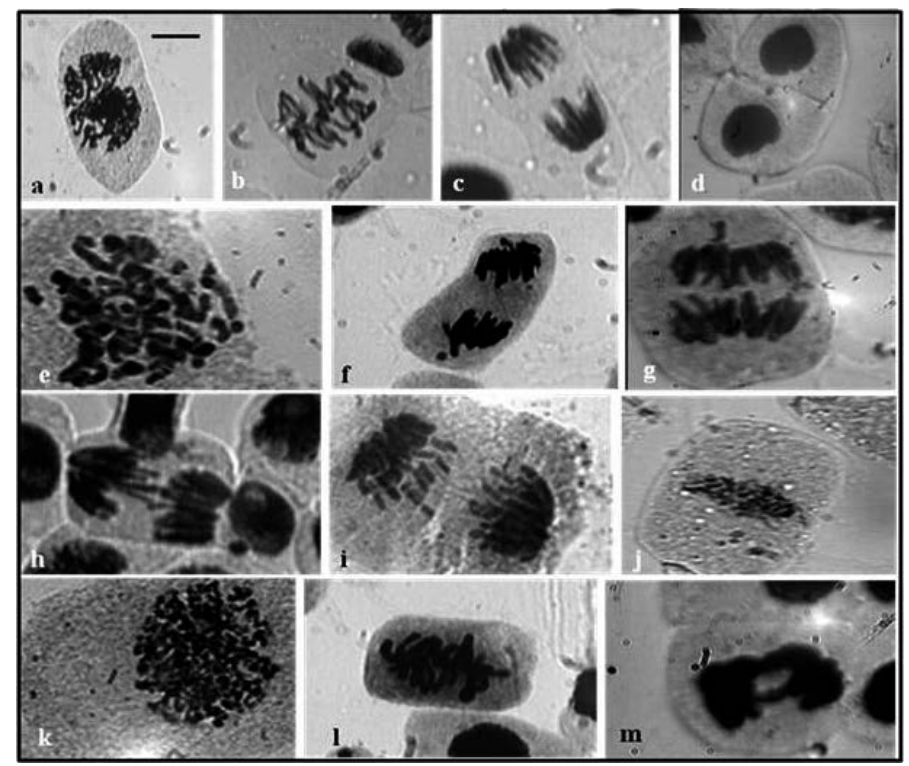

Fig. 7. Normal mitotic cells in the control and division anomalies in urea-treated cells.

a) Normal prophase, b) normal metaphase, c) normal anaphase, d) normal telophase, e) chromosome fragmentation at metaphase, $\mathrm{f}$ ) disorientation at anaphase, g) precocious movement of chromatid at anaphase, h) anaphase bridge, i) laggards, j) clumping at metaphase, k) chromosome fragmentation at prophase, 1) disorientation of chromosomes at metaphase, $\mathrm{m}$ ) clumped anaphase with bridge ( $\mathrm{a}-\mathrm{c}, \mathrm{f}, \mathrm{h}, 1$ and $\mathrm{m}, \mathrm{bar}=25 \mu \mathrm{m}),(\mathrm{d}, \mathrm{e}, \mathrm{g}, \mathrm{i}, \mathrm{j}$ and $\mathrm{k}$, bar $=10 \mu \mathrm{m})$.

toxicity (Britto and Kronzucker 2002, Qin et al. 2011, Qi et al. 2012). The inhibition of primary root growth by inhibiting cell elongation and division are toxicity symptoms as reported by Qin et al. (2011) in Arabidopsis. A high ratio of ammonium to nitrate enhanced the uptake of P (Lorenzo et al. 2000a) and $\mathrm{N}$ (Lorenzo et al. 2000b) during shoot elongation by rose plants. This can be explained by the preferential uptake of $\mathrm{NH}_{4}$ as compared with $\mathrm{NO}_{3}$ (Marschner 1995), and also by the reduction of solution $\mathrm{pH}$ (Feigin et al. 1986). Increased ratio of $\mathrm{NH}_{4}: \mathrm{NO}_{3}$ : urea has been reported to cause zero yield and reduction in $\mathrm{pH}$ in roses (Bar-Yosef et al. 2009). Reduction in $\mathrm{pH}$ is a consequence of nitrification and $\mathrm{NH}_{4}$ uptake by the plant. Low yield could have been due to $\mathrm{NH}_{4}$ toxicity and inhibition of $\mathrm{Ca}$ and $\mathrm{K}$ uptake as $\mathrm{NH}_{4}$ impedes $\mathrm{Ca}$ uptake, which reduces root growth at low $\mathrm{pH}$. The role of $\mathrm{NH}_{4}: \mathrm{NO}_{3}$ and its correlation with salinity and $\mathrm{pH}$ has previously 


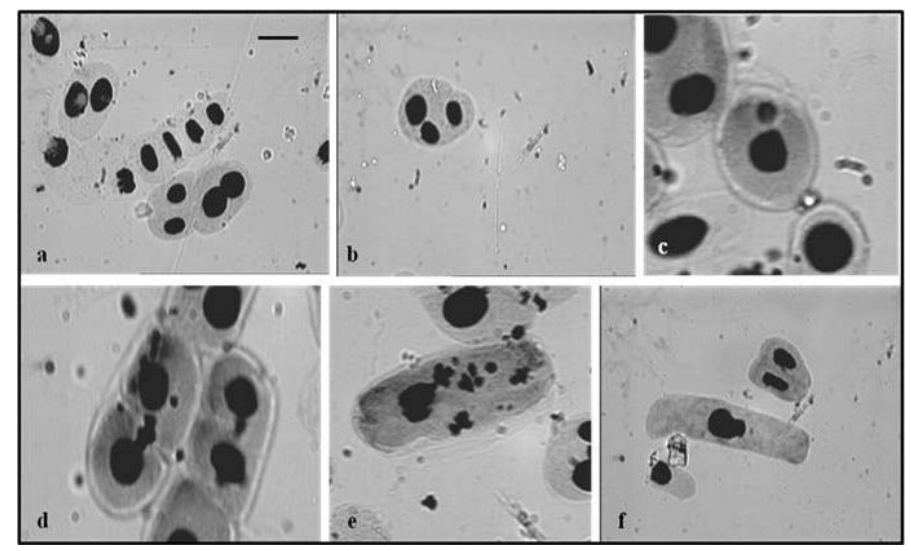

Fig. 8. Interphase nuclear abnormalities. a) Binucleate cells, b) trinucleate cell, c) cell with one micronucleus, d) cell with chain of micronuclei, e) cell with eight to nine micronuclei, f) nuclear budding $(\mathrm{a}-\mathrm{f}$, bar $=25 \mu \mathrm{m})$.

been shown in roses by Cabrera (2001) and Bar-Yosef et al. (2009). From the second week onwards, levels of nitrate increased, and consequently $\mathrm{NH}_{4}: \mathrm{NO}_{3}$ started to decline. During this period (14 DAT to $28 \mathrm{DAT}$ ), interphase nuclear abnormalities (Fig. 8) started appearing along with abnormalities of dividing cells as shown in Figs. 5 and 6. Most of the cells during this period got arrested at the interphase stage and did not enter into the $M$ phase of the cell cycle, which is why the mitotic index during this period is low. This observation correlated with higher nitrate levels, as has been reported by Okushima et al. (2011). According to them, high nitrate levels arrest the cells at $\mathrm{G} 1 / \mathrm{S}$ by suppression of mitotic reporter genes for $C D K B 2 ; 1$ and $C Y B 1 ; 1$. The present analysis showed the induced cytological disturbances in root tip cells as an effect of urea. To conclude, urea is capable of inflicting irreversible cytological damage in plants if used consistently and indiscriminately, as such practice disturbs the $\mathrm{NH}_{4}: \mathrm{NO}_{3}$ in the soil.

\section{Conclusion}

Variations in cytological anomalies observed at regular intervals of time in the present study led to an assumption that the indiscriminate use of urea as fertilizer may induce an array of chromosomal variations in the plant systems due to a disturbance of the ammonium-nitrate balance in the soil.

\section{Acknowledgement}

The authors thank the Council of Scientific and Industrial Research (CSIR), India, for financial assistance.

\section{References}

Bar-Yosef, B., Mattson, N. S., and Lieth, H. J. 2009. Effects of $\mathrm{NH}_{4}: \mathrm{NO}_{3}$ : urea ratio on cut roses yield, leaf nutrients content and proton efflux by roots in closed hydroponic system. Sci. Hortic. 122: 610-619.

Britto, D. T., and Kronzucker, H. J. 2002. $\mathrm{NH}_{4}^{+}$toxicity in higher plants: a critical review. J. Plant Physiol. 159: $567-584$.

Cabrera, R. I. 2001. Effect of $\mathrm{NaCl}$ salinity and nitrogen fertilizer formulation on yield and nutrient status of roses. Acta Hortic. 547: 255-260.

Clay, D. E., Malzer, G. L., and Anderson, J. L. 1990. Ammonia volatilization from urea as influenced by soil temperature, soil water content, and nitrification and hydrolysis inhibitors. Soil Sci. Soc. Am. J. 54: 263-266. 
Errebhi, M., and Wilcox, G. E. 1990. Plant species response to ammonium-nitrate concentration ratios. J. Plant Nutr. 13: 1017-1029.

Feigin, A., Ginzburg, C., Gileadi, S., and Ackerman, A. 1986. Effect of $\mathrm{NH}_{4} / \mathrm{NO}_{3}$ ratio in nutrient solution on growth and yield of greenhouse roses. Acta Hortic. 189: 127-132.

Jackson, M. L. 1967. Soil Chemical Analysis. Prentice Hall of India Pvt. Ltd., New Delhi.

Khaldi, F., Berrebbah, H., and Djebar, M. R. 2012. Toxic effect of fertilizers on inferior plants resed as biological models In: Proc. International Conference on Applied Life Sciences (ICALS 2012), Turkey. pp. 205-210.

Koca, S. 2008. The cytogenetic effects of Sheffer A: a liquid fertilizer and growth regulator in root tip cells of Vicia faba L. C.B.U. J. Sci. 4.1: 121-126.

Kovalchuk, O., Kovalchuk, I., Arkhipov, A., Telyuk, P., Hohn, B., and Kovalchuk, L. 1998. The Allium cepa chromosome aberration test reliably measures genotoxicity of soils of inhabited areas in the Ukraine contaminated by the Chernobyl accident. Mutat. Res. 415: 47-57.

Lorenzo, H., Cid, M. S., Siverio, J. M., and Caballero, M. 2000a. Influence of additional ammonium supply on some nutritional aspects in hydroponic rose plants. J. Agric. Sci. 134: 421-425.

Lorenzo, H., Cid, M. S., Siverio, J. M., and Ruano, M. C. 2000b. Effects of sodium on mineral nutrition in rose plants. Ann. Appl. Biol. 137: 65-72.

Marschner, H. 1995. Mineral Nutrition of Higher Plants, second ed. Academic Press, San Diego.

Okushima, Y., Inamoto, H., and Umeda, M., 2011. A high concentration of nitrate causes temporal inhibition of lateral root growth by suppressing cell proliferation. Plant Biotechnol. (Tsukuba) 28: 413-416.

Qi, X., Wu, W., Shah, F., Peng, S., Huang, J., Cui, K., Liu, H., and Nie, L. 2012. Ammonia volatilization from ureaapplication influenced germination and early seedling growth of dry direct-seeded rice. Scientific World Journal. 2012, Article ID 857472,7 pages. doi: 10.1100/2012/857472.

Qin, C., Yi, K. K., and Wu, P. 2011. Ammonium affects cell viability to inhibit root growth in Arabidopsis. J. Zheijang Univ. Sci. B 12: 477-484.

Sharma, A. K., and Sharma, A. 1980. Chromosome Technique-Theory and Practice. Butterworths, London.

Taghavi, T. S., Babalar, M., Ebadi, A., Ebrahimzadeh, H., and Asgari, M. A. 2004. Effects of nitrate to ammonium ratio on yield and nitrogen metabolism of Strawberry (Fragaria $\times$ Ananassa cv. Selva). Int. J. Agric. Biol. 6: 994-997.

Zhang, H., and Forde, B. G. 2000. Regulation of Arabidopsis root development by nitrate availability. J. Exp. Bot. 51: 5159. 